\title{
Brief Analysis on Xi Jinping's Thought of Socialist Image with Chinese Characteristics in the New Era
}

\author{
Li Chunyan ${ }^{1}$ \\ School of Marxism, Huazhong University of Science and \\ Technology, Wuhan Hubei 430074
}

\author{
Zhang Zilong ${ }^{2 *}$ \\ Party Committee Propaganda Department, Hubei University \\ of Chinese Medicine \\ Wuhan, Hubei 430074
}

\begin{abstract}
In order to explore the social image thought in $\mathrm{Xi}$ Jinping's national governance thoughts, this paper combines practice interpretation method and historical logic method to sort out relevant documents, concluding that the thought of "building a prosperous, democratic, civilized, harmonious and beautiful socialism modernized major country by the middle of this century" put forward by $\mathrm{Xi}$ Jinping contains the valuable thoughts of "which kind of overall social image we should build and how to design the specific image of Chinese society". The innovative point is the initial exploration of Xi Jinping's thoughts from the perspective of social image theory.
\end{abstract}

Keywords-Xi Jinping; The new era; Socialism with Chinese characteristic; Social image

\section{INTRODUCTION}

In the report for the 19th National Congress of the Communist Party of China, as a strategist, politician, and ideologist, General Secretary $\mathrm{Xi}$ Jinping gave scientific answers to "which kind of Chinese characteristic socialism should we build in the new era, and how to build the Chinese characteristic socialism in the new era", and this is not only the enrichment and development of Chinese characteristic socialism theory in the new era, but also the third leap for the localization of Marxism in China, and can also clearly express the political ideal image appeal, the systematic theory and clear practice, and also express General Secretary Xi Jinping's building of current Chinese social image and the design of ideal Chinese social image. Since China develops to where it is today, as a socialism society with its own characteristics, it is requested to design and build a kind of systematic and multi-dimensional specific image. General Secretary Xi Jinping applied the historical materialism and dialectical materialism theory in the observation and summarization of human history evolution and scientific socialism development, and conducted design and elaboration for the specific image of Chinese characteristic socialism from five dimensions, including economy, policy, culture, society, and ecology.

\section{Design AND BuILD A Socialism ECONOMIC IMAGE With THE COMMON PRosperity OF All PEOPLE}

As for the essence of social image, it belongs to superstructure, with the implications of ideological speaking right and cultural speaking right. Since economic foundation decides the superstructure, the design and building of economic image is the problem mostly reflected by Genera Secretary Xi Jinping since the 18th National Congress of the Communist Party of China, and from November, 2012 to March, 2017, he had delivered series of speeches and gave instructions considering how to develop Chinese characteristic socialism economy, how to liberate and develop productivity, how to implement the new development concept, how to promote reform and opening up, how to develop economy through taking the people as the center, how to lead the new normal of economic development, and the promote the supplyside structural reform, etc., and totally there were about 120 important references, and all of these references along with the report of the 19th National Congress of the Communist Party of China jointly designed and built the Chinese characteristic socialism economic image of "the common prosperity of all people". During the 18th Sixth Plenary Session of the Party, General Secretary Xi Jinping firstly put forward "the practice of people-centered development thought" , and emphasized on the central position of people in economic development. In 2016 afterwards, he also put forward "the request of gradually realizing common prosperity" when giving instructions about studying and implementing the spirits of the 18th Sixth Plenary Session of the Party, and emphasizing on "sticking to people-centered development thought." During the period, the economic image of common prosperity for all people has been vividly portrayed. In 2017, the 19th National Congress of the Communist Party of China was successfully convened in Beijing, and during the fourth part of plenary lecture, Comrade $\mathrm{Xi}$ Jinping pointed out that, "building our country into a socialism modernized power in the middle of this century, and become a country with leading comprehensive national strength and international influence, and all people can basically realize common prosperity....." Thus, the Chinese characteristic socialism economic image: "the common prosperity of all people" can be clearly drawn up. 


\section{Design ANd BUILD A SOCIALISM Political IMAGE WITH MODERNIZED GOVERNANCE CAPACITY AND SYSTEM}

Foucault thought that modernity should also consider how to govern people as a key, except for considering the harmonious relationship between people and the nature. Under the big background of modernity, as one of the answers for "how to govern people", Chinese characteristic socialism must build distinctive political image. General Secretary Xi Jinping conducted in-depth reflection and practice to design and build democratic political image from how to stick to the political development road of Chinese characteristic socialism, how to stick to the organic integration of party leadership, people as the masters of their own country and legal state governance, hot to promote political system reform, convert government function, how to implement the ethnic policy and religious policy of the party, and how to consolidate patriotic united front and other aspects, and meanwhile, answered the question of "how to govern people", and also reflected the three characteristics for designing and building political image in the state governance strategy of "state governance system and governance capacity modernity": firstly, it is the political image sticking to Chinese communist party leadership and socialism system; secondly, it is the state governance system and capacity modernity image; thirdly, it is Chinese characteristic socialism political image, rather than westernization and capitalization. The state governance system and governance capacity modernity are the important contents about Chinese characteristic socialism thought in the new era, and it can not only reveal the fundamental historical task for the practice of Chinese characteristic socialism in the future, it has also constructed the self-confidence dimension of Chinese characteristic socialism political image from governance objective, governance subject, governance contents, and governance mode.

\section{DESIGN AND BUILD A PROSPEROUS AND CIVILIZED SOCIALISM CULTURAL IMAGE}

As the overall image of a social form, social image isn't always related to economy, policy, military and other strength. Social political system, cultural attraction, foreign publicity strategy, ideological orientation, value concept, and even geopolitics factors shall not be neglected, of which the culture and value concept exerts the biggest decisive effect, and the social image without cultural cohesion and core value concept doesn't have a soul or vitality. Therefore, if we say that the building of Chinese characteristic socialism image in the new era mainly relies on economic image and political image at home, it should rely more on cultural image at abroad to win the recognition of other social images with different economic systems and political systems. Moreover, the current cultural status of Chinese society is the mixture of various cultures, and it not only includes the mixture of dominant culture, emerging culture, and remaining culture, but also includes the mixture of western culture, national culture, and revolution culture. The culture is diversified by the internal cohesion is relatively low. Therefore, after the 18th National Congress of the Communist Party of China, Comrade Xi Jinping not only paid attention to the leadership, management right and speaking right of ideological work as well as the cultivation and practice of socialism core value concept, but also paid attention to promoting the comprehensively prosperous socialism cultural career, designing and building prosperous and civilized cultural image to promote the cultural cohesion and guidance function. In his view, General Secretary $\mathrm{Xi}$ Jinping held that prosperous culture was closely related to the great rejuvenation of Chinese nation, and it was the soul of the country and nationality ; the report for the 19th National Congress of the Communist Party of China further emphasized on "affirming cultural confidence, and promoting the prosperous and flourishing socialism culture," because "without high cultural confidence, or prosperous and flourishing culture, there will be no great rejuvenation of Chinese nation." Meanwhile, specific requirements and measures were put forward for the design and building of prosperous and civilized cultural image from five aspects, including the leadership of ideological work, the socialism core value concept, ideological and moral education, socialism art, cultural career and cultural industry.

\section{DESIGN AND BuILD A VigOROUS HaRMONiOUS SOCIALISM SOCIAL IMAGE}

Although the state is the key force for the reform of social development, and the activity motivation influencing society, the state has always been a component of the society. After the reform and opening up, under the cultivation of socialism market economy, Chinese characteristic socialism market economy has cultivated and developed a kind of emerging social force: civil society, which can further indicates that the integration status of traditional state and society has changed. From November, 2011 to September, 2017, Comrade Xi Jinping published a series of important discussions on socialism social construction in above 140 references, and conducted theoretical and practical explorations on Chinese characteristic socialism construction from education, employment, incomes, poverty alleviation, medical treatment and health care, social insurance, social governance and other fields related to people's livelihood, and the thought about the Chinese characteristic socialism social image has also been gradually drawn up in this process. First of all, after the 18th National Congress of the Communist Party of China, General Secretary Xi Jinping has insisted that historical inheritance has stood at a new height again and reflected on the construction of socialism and harmonious society. Secondly, since the motivation of social vigor is the inevitable choice for constructing harmonious society and also the reality need for realizing Chinese dream, the 18th Third Plenary Session of the Party put forward "liberating and reinforcing social vitality"; on this basis, Comrade Xi Jinping firstly put forward "a good society shall be not only vigorous, but also harmonious and ordered" during the investigation at Zhejiang in 2015. Thus, Chinese characteristic socialism social image thought is gradually enriched, and then in the report for the 19th National Congress of the Communist Party of China, it was clearly pointed out that, the objective for social construction is "basically forming the modernized social governance pattern, and making the society vigorous, harmonious and ordered.", and this marks that General Secretary Xi Jinping has drawn up the initial design and building of vigorous and harmonious social image. 


\section{Design AND BuILd A Beautiful Socialism ECOLOGICAL IMAGE}

The rise and decline of a society and a country often depends on whether it can seize the pulse of human civilization development, and the current human civilization has started to convert towards ecological civilization from industrial civilization, and the Party Central Committee led by $\mathrm{Xi}$ Jinping also paid more attention to the ecological environment of the society, the key word of "beautiful China" has frequently occurred in the speech, report, and congratulatory letters. In the 6th Collective Study for the 18th Bureau of Central Committee held in May, 2013 and the ecological civilization Guizhou International Forum held in July of the same year, he delivered important speeches for two times considering constructing "beautiful China" and the sustainable development of Chinese nation as well as the relationship with the great rejuvenation of Chinese nation, designed and built a wonderful blueprint of "beautiful China" for ecological civilization construction. In April, 2014, when participating in the voluntary tree planting activities at the capital, he put forward guidance opinions from forestry resources and beautiful China, and requested to "cultivating, protecting and developing well the forestry resources of our country" Meanwhile, in October, 2015, he put forward that, the beautiful ecological image constructed by Chinese characteristic socialism can not only accelerate the construction of resource-saving, and environmentally-friendly society, but also make a new contribution to the ecological safety worldwide. In 2016, he also further emphasized in Striving for Constructing World's Scientific and Technical Power that, "relying on scientific and technical innovation to construct beautiful China with blue sky, green ground and clear water" All the aforementioned contents can sufficiently indicate that, over the years, General Secretary Xi Jinping has always regarded "beauty" as a key word for the ecological construction of Chinese characteristic socialism, and finally in the report for the 19th National Congress of the Communist Party of China, he separately listed "constructing beautiful China" as the ninth part of the report, and elaborated the concept and requirements for the ecological construction of Chinese characteristic socialism from four perspectives, including green development, environment governance, ecological protection and supervision system, and it has also specified the road, direction and objective for constructing beautiful ecological image of Chinese characteristic socialism.

\section{CONCLUSION}

Social image is the reflection of a kind of epistemological category for social reality. The initial construction of $\mathrm{Xi}$ Jinping's Chinese characteristic socialism image thought for the new era is the scientific answers to "which kind of Chinese characteristic socialism image should we build, and how to build Chinese characteristic socialism image" from strategic height through applying dialectical thinking mode to deeply study and judge the social development trend of human beings based on correctly seizing Chinese characteristic socialism history, culture, tradition, and practice. The study of $\mathrm{Xi}$ Jinping's Chinese characteristic socialism image thought is quite meaningful for promoting the construction career of Chinese characteristic socialism, and creating the new situation for China considering the domestic and overseas publicity work. It not only means that Chinese socialism road exploration has entered into a new period, but also means that the design and building of Chinese characteristic socialism image have started a brand new journey. Meanwhile, we should also notice that the society is developing and changing, so the design and building of social image are also dynamic. This means that the Chinese characteristic socialism image in the new era is the epistemology achievement formed in the historical process, and is more like an epistemology process of constant perfection and development in the historical process, and it will certainly be constantly explored and innovated along with the development of Chinese characteristic socialism career.

\section{ACKNOWLEDGMENT}

Fund Project: This article is the phased achievement for 2017 Humanistic and Social Science Fund Plan Project of the Ministry of Education [17YJA860007]

About the Author: Li Chunyan (1976-), female, the doctoral candidate for School of Marxism, Huazhong University of Science and Technology, and mainly studies Marxism Social Epistemology.

Corresponding Author: Zhang Zilong (1964-), male, the Minister and Professor for the Party Committee Propaganda Department of Hubei University of Chinese Medicine, and mainly studies the ideological management in universities. 


\section{REFERENCES}

[1] Party Literature Research Center of the CPC Central Committee. Notes about the Discussion of $\mathrm{Xi}$ Jinping on the Socialism Economic Construction [M]. Beijing: Central Party Literature Press, 1997: 40-41, 29.

[2] Party Literature Research Center of the CPC Central Committee. Notes about the Discussion of $\mathrm{Xi}$ Jinping on the Socialism Political Construction [M]. Beijing: Central Party Literature Press, 2017: 8.

[3] He Xianming. Realizing the Valid Governance of Socialist Country [J] Journal of the Party School of CPC Zhejiang Provincial Committee. 2016 (4).

[4] [America] Liu Kang. Power Image___Reflection on Culture and Value Concept [M]. Shanghai: Shanghai People's Publishing House, 2015 : 216-217.

[5] Party Literature Research Center of the CPC Central Committee. Notes about the Discussion of $\mathrm{Xi}$ Jinping on the Socialism Cultural Construction [M]. Beijing: Central Party Literature Press, 2017: 5、 7.

[6] Xi Jinping. Realizing the Comprehensive Establishment of a Moderately Prosperous Society, and Obtaining the Great Victory of Chinese Characteristic Socialism in the New Era-the Report during the 19th National Party Congress [R]. Beijing: People's Publishing House, 2017:28-41.

[7] Decision of CPC Central Committee on Several Major Issues for Comprehensively Deepening Reform [M]. Beijing: People's Publishing House, 2013: 18.

[8] Party Literature Research Center of the CPC Central Committee. Notes about the Discussion of Xi Jinping on the Socialism Social Construction [M]. Beijing: Central Party Literature Press, 2017: 130.

[9] Party Literature Research Center of the CPC Central Committee. Notes about the Discussion of $\mathrm{Xi}$ Jinping on the Socialism Ecological Civilization Construction [M]. Beijing: Central Party Literature Press, 2017: 5-117. 